AUSTRALIAN JOURNAL OF BASIC AND
APPLIED SCIENCES
ISSN:1991-8178
DOSSN: $2309-8414$

\title{
Nitrogen Dose Fractionation In Different Stages of Application In Wheat
}

${ }^{1}$ ClaudiaManteli, ${ }^{2}$ Eluis Fabrício Fabiane, ${ }^{3}$ Alberto Ricardo Stefeni, ${ }^{4}$ Marciéli da Silva, ${ }^{5}$ Barbara Elis Santos Ruthes, ${ }^{6}$ Gisely Correa de Moura

${ }^{1}$ Department of Agronomy, Federal Teaching Union of Southwest Paraná (UNISEP), DoisVizinhos, PR, 85660-000, Brazil.

${ }^{2}$ Agronomist Engineer, Street LeopoldoPrellifer, Verê - PR, 85585-000, Brazil.

${ }^{3}$ Department of Agroecosystems, Federal Technological University of Paraná (UTFPR), DoisVizinhos, PR, 85660-000, Brazil.

${ }^{4}$ Department of Agroecosystems, Federal Technological University of Paraná (UTFPR), DoisVizinhos, PR, 85660-000, Brazil.

${ }^{5}$ Department of Agroecosystems, Federal Technological University of Paraná (UTFPR), DoisVizinhos, PR, 85660-000, Brazil.

${ }^{6}$ Department of Agroecosystems, Federal Technological University of Paraná (UTFPR), DoisVizinhos, PR, 85660-000, Brazil.

Address For Correspondence:

Claudia Manteli, Department of Agronomy, Federal Teaching Union of Southwest Paraná (UNISEP),DoisVizinhos, PR, 85660-000, Brazil. E-mail: claudiamanteli@gmail.com

\section{ARTICLE INFO}

\section{Article history:}

Received 12 October 2017

Accepted 22 December 2017

Available online 31 December 2017

Keywords:

Triticumaestivum L., Nitrogen

Fertilization, Tillering, Booting,

Trimming.

\begin{abstract}
A B S T R A C T
Wheat has high grain yield potential, however in practice such potential has demonstrated low expression. Many studies are carried out on the crop in order to maximize its productivity due to its food importance. Nitrogen is the nutrient most required by this crop, therefore essential for its development. This research had the objective of evaluating the application of a dose of nitrogen, fractionated at different times. The experiment was carried out in the experimental field of UNISEP, DoisVizinhos - PR, in Red Dystrophic UmbricNitosol soil type, conducted in a randomized block design, with five replications. The treatments consisted of the fractionation of the application of the dose of $150 \mathrm{~kg}$ ha- 1 nitrogen, being: $0 \mathrm{~kg}$ ha- $1 ; 50$ $\mathrm{kg}$ ha-1 applied in tillering, rubbering and earning; $75 \mathrm{~kg}$ ha-1 applied in tillering and rubbering; $150 \mathrm{~kg}$ ha-1 applied in tillering. The source of nitrogen used was urea (45$00-00)$. The plots present an area of $15 \mathrm{~m} 2$, consisting of 17 lines of $0.17 \mathrm{~m} \mathrm{x} 5 \mathrm{~m}$ in length. The number of tillers, plant height, dry matter mass, severity of leaf diseases, hectolitre weight and productivity were evaluated. The results were submitted to analysis of variance and when significant to the Tukey test $(\mathrm{p}<0.05)$. Fractionation of the studied $\mathrm{N}$ dose, under the specific conditions, showed no significant difference for plant height, dry matter and severity. The fractionation of the $150 \mathrm{~kg}$ ha- 1 dose at different times of application in the wheat crop influenced the number of tillers, hectolitre weight and productivity. It was concluded that different doses and fractionation of these should be tested in future studies to obtain more conclusive data.
\end{abstract}

\section{INTRODUCTION}

Wheat has high grain yield potential, but in practice such potential has shown low expression. Therefore, it is necessary to know better the characteristics of the production, phenological stages, its components of productivity, management and nutrition. Among the nutritional requirements, the nitrogen application is a limiting factor of productivity, since this element is one of the most absorbed by plants of this family.

Nitrogen (N) has an important role, which influences the development and productivity of the crop. This is a constituent of enzymes, proteins, nucleic acids and amino acids. The assimilation of the same by the plant undergoes different types of interference, depending on the edaphoclimatic conditions (Araújo and Machado, 2006). However, the absence of this element restricts vital development processes such as evapotranspiration and water use efficiency, affects the interception of the radiation and decreases its efficiency of the use of radiation (Megda et al, 2009).

Open Access Journal

Published BY AENSI Publication

(C) 2017 AENSI Publisher All rights reserved

This work is licensed under the Creative Commons Attribution International License (CC BY).

http://creativecommons.org/licenses/by/4.0/

(c) () Open Access

ToCite ThisArticle: Claudia Manteli, Eluis FabrícioFabiane, Alberto Ricardo Stefeni, Marciéli da Silva, Barbara Elis Santos Ruthes, Gisely Correa de Moura, Nitrogen dose fractionation in different stages of application in wheat. Aust. J. Basic \& Appl. Sci., 11(16): 56-61, 2017 
For the cultivation of wheat, the demand in $\mathrm{N}$ is highlighted from the emergency until the emission of the seventh leaf. In the initial period it is important to increase the number of spikelets in the spikes, increasing the number of grains. In the final stages it will help increase the number of stems per area (Souzaet al, 2013).

The application of nitrogen fertilization must be performed before precipitation of medium intensity occurs, for better absorption by the plant. However, there are also problems that occur with excessive rainfall or for a prolonged period, which causes leaching and runoff. Thus, the correct use and time of application of the fertilizer, will increase the quality and quantity of the cereal produced (Costa et al., 2003; Silva and Azevedo, 2009). Thus, it is important to note the great importance of the application in the correct period, but it is a questioned factor currently in the management of grasses in the no-tillage system (Teixeira Filho et al., 2010). In this way, the research aimed to evaluate the influence of the application of nitrogen, fractionated at different stages, on the growth and development of the wheat crop.

\section{MATERIAL AND METHODS}

The experiment was conducted in the experimental area of the Teaching Union of Southwest of Paraná UNISEP, located in DoisVizinhos - PR. Region that is understood by the third paranaense plateau, and average altitude of $520 \mathrm{~m}$.

The soil is classified as a Red Dystrophic UmbricNitosol, with undulating relief and clayey texture (Bhering et al., 2008). The predominant climate is the mesothermal wet subtropical (Cfa), as classified by Köppen (Alvares et al., 2014).

The planting density was $450 \mathrm{~m} 2$ plants with $0.17 \mathrm{~m}$ line spacing. The seeder used had a continuous flow system. The seeds were treated using commercial dose of systemic insecticide based on Imidacloprid + Thiodicarb.

The area for implantation of the experiment was dried 40 days before planting. The soil was corrected based on soil analysis performed in the area. The basic fertilization used was equivalent to 8-20-18 (Nitrogen - P2O5 K2O), with $292 \mathrm{~kg}$ ha-1.

The statistical design was a randomized block design, with five replications. The treatments consisted of the fractionation of the application of the dose of $150 \mathrm{~kg}$ ha- 1 of $\mathrm{N}$, being: $0 \mathrm{~kg}$ ha-1; $50 \mathrm{~kg} \mathrm{ha}-1$ applied to tillering, booting and trimming; $75 \mathrm{~kg}$ ha-1 applied in tillering and booting; $150 \mathrm{~kg}$ ha-1 applied to tillering. The source of nitrogen used was urea (45-00-00). The plots presented an area of $15 \mathrm{~m} 2$, consisting of 17 lines of $0.17 \mathrm{~m} \times 5 \mathrm{~m}$ in length.

In order to compare the effects of the treatments were evaluated the variables, disease severity, number of tillers, plant height, plant dry mass, productivity and hectolitre weight.

For disease severity (\%), the evaluations were done before the application of fungicides on three occasions. For this, three plants per plot were removed, respecting $0.20 \mathrm{~m}$ of border for further evaluation. To evaluate the results, the diagrammatic scale of the Brazilian Agricultural Research Company (Embrapa, 2014) was used.

To measure the number of tillers, the counting was performed at the tillering stage, with $0.25 \mathrm{~m} 2$ of plants being collected per plot.

Plant height $(\mathrm{cm})$ was measured with the aid of a graduated ruler at three different stages of development (tillering, booting and trimming), and 20 plants were randomly evaluated per plot.

To evaluate the mass of the plant dry matter (DM), $0.25 \mathrm{~m} 2$ of plants were collected per plot, with the aid of a marker, which were placed in paper bags, measured in electronic balance, considering four decimal places after comma. After that, the collected material was taken to drying in a continuous air flow oven where it remained for three days, with a fixed temperature of $55^{\circ} \mathrm{C}$, for later weighing. The applications of $\mathrm{N}$ and the evaluations were carried out in a minimum period of 20 days of interval.

As a parameter of productivity, the hectolitre weight was evaluated. When the culture reached the stage of physiological denaturation, we performed collections of $2.0 \mathrm{~m} 2$ of plants of the area of each plot, being hand tracked, then weighed and the hectolitre weight.

The hectolitre weight determined from the use of the DalleMolle ${ }^{\circledR}$ scale, being verified according to the Seed Analysis Rules (BRASIL, 1992), the results being expressed in kg hL-1.

The data were submitted to the analysis of the variance and, when significant, to the Tukey test $(\mathrm{p}<0.05)$, through the statistical assistance program Assistat Software (Silva and Azevedo, 2009).

\section{RESULTS AND DISCUSSION}

For the variable MS, there was no significant difference by analysis of variance, in any of the three stages of development evaluated (Table 1). The results of MS, in the three evaluations, can be inferred with data from Embrapa Wheat (2003), mainly in the initial times, because it is a period of increment of leaf area, it is common not to have statistical difference. 
Espindula (2010) also verified the increase of the dry matter as the $\mathrm{N}$ dose increased with application of 120 $\mathrm{kg} / \mathrm{N} \mathrm{ha}^{-1}$ verified a production of $12,000 \mathrm{~kg} \mathrm{ha}^{-1}$. Souza et al. (2013) verified that the maximum dry matter production of the aerial part occurred in the dose of $\mathrm{N} 165 \mathrm{mg} \mathrm{dm}^{-3}$ and of the root with $54.44 \mathrm{mg} \mathrm{dm}^{-3}$.

Table 1: Dry matter mass $(\mathrm{DM})\left(\mathrm{Kg} \mathrm{ha}^{-1}\right)$, at tillering, booting and trimming (units per plants) in wheat crop under dose fractioning of Nitrogen. DoisVizinhos-PR. Safra 2014.

\begin{tabular}{llll}
\hline & $\mathrm{DM}$ & $\mathrm{DM}$ & DM \\
Dose Fractioning of Nitrogen $\left(\mathrm{Kg} \mathrm{ha}^{-1}\right)$ & Tillering & Booting & $115,20^{\mathrm{NS}}$ \\
\hline 0 & $37,12^{\mathrm{NS}}$ & $93,44^{\mathrm{NS}}$ & 130,56 \\
150 & 38,40 & 96,64 & 96,00 \\
$75+75$ & 37,76 & 104,32 & 129,92 \\
$50+50+50$ & 38,40 & 97,28 & 15,51 \\
\hline $\mathrm{CV}(\%)$ & 8,51 & 13,18 & \\
\hline
\end{tabular}

$\mathrm{CV}(\%)$ : Coefficient of variation. NS: Not significant.

Valério et al. (2009) emphasizes that the ability of wheat to balance the number of plants, the emission of tillers and the accumulation of assimilated in its tissues is a variable of the potential of the cultivar used and the conditions that it will be exposed. During the experiment the crop was exposed to long periods with excess rainfall and in other periods water deficit occurred, which may have motivated the obtaining of non-significant results of dry matter mass.

The results of this study were similar to those previous of this study (Espindula, 2010). In this study, the application of $\mathrm{N}$ was not an adequate and correct alternative, since it did not obtain a significant and effective difference in its evaluations within the same crop, since its application was performed 19 days after sowing. Knowing that other factors may interfere with nutrient absorption, they may have helped achieve such an outcome, such as excessive rainfall in one period and lack of rainfall in another period, during the experiment.

Jesus and Ferreira (2009) ponder that climatic factors can intervene in the expression of the results, not leaving available the nutrient that was applied to the plant, being that this material can be leached, interfering the non-expressed responses to the action on the plant. They also cite that the appearance of diseases above the common plant are some of the symptoms of excessive rainfall.

Plant height did not present statistical difference between treatments (Table 2). This corroborates with Valério et al. (2009), when they affirm that the potential of the cultivar can determine its development under field conditions.

Table 2: Plant height $(\mathrm{PH})(\mathrm{cm})$ at tillering, booting and trimming, in wheat crop under dose fractioning of Nitrogen. DoisVizinhos-PR. Safra 2014.

\begin{tabular}{llll}
\hline & $\mathrm{PH}$ & $\mathrm{PH}$ & $\mathrm{PH}$ \\
Dose Fractioning of Nitrogen $\left(\mathrm{Kg} \mathrm{ha}^{-1}\right)$ & Tillering & Booting & Trimming \\
\hline 0 & $27,35^{\mathrm{NS}}$ & $58,81^{\mathrm{NS}}$ & $72,95^{\mathrm{NS}}$ \\
150 & 27,00 & 62,77 & 71,93 \\
$75+75$ & 27,18 & 60,05 & 73,72 \\
$50+50+50$ & 27,88 & 57,81 & 74,24 \\
\hline $\mathrm{CV}(\%)$ & 3,67 & 11,76 & 3,08 \\
\hline
\end{tabular}

$\mathrm{CV}(\%)$ : Coefficient of variation. NS: Not significant.

TeixeiraFilho et al. (2010) also confirmed a lack of significant difference in an area where there was no application of $\mathrm{N}$ for the other areas applied in any of the stages tested, also verified by Yano et al. (2005) and different from what Zagonel (2002) found. Another factor that could be observed was the absence of lodging of the plants, including the plants that received the highest doses of nitrogen (Pettinelli et al., 2002).

According to Zagonel and Fernandes (2007), plant height is directly attached to bedding and can be affected by the dose of $\mathrm{N}$, among other factors.

As the experiment by Melero et al. (2013), which states, the higher the $\mathrm{N}$ doses, the greater the tendency of the plants to be as a consequence of higher lodging. In order to reduce this problem, it is possible to use growth regulators, which have the function of reducing the size of plants.

One of the hypotheses, which helps to answer the lack of difference of an area where there was no application of $\mathrm{N}$ for the other applied areas, may be the excess of precipitation and also the place where the experiment was performed, with a low fertility, where it was not crop rotation.

The severity variable also showed no significance (Table 3). Diseases that were verified during the experiment, such as leaf spot, rust and powdery mildew, were present in a larger quantity during the tillering period, and others such as Fusarium Head Blight (FHB) and blast (Pyriculariagrisea), in the maturation stage. These facts can be justified by the excess of rain, climatic conditions not adequate in some periods and also by the variety does not present resistance (IAPAR, 2008). 
Tabela 3: Severity (\%) at tillering, booting and trimming, in wheat crop under dose fractioning of Nitrogen.DoisVizinhos-PR. Safra 2014.

\begin{tabular}{llll} 
Tabela 3: Severity $(\%)$ at tillering, booting and trimming, in wheat crop under dose fractioning of Nitrogen.DoisVizinhos-PR. Safra 2014. \\
\hline & $\mathrm{PH}$ & $\mathrm{PH}$ & $\mathrm{PH}$ \\
Dose Fractioning of Nitrogen $\left(\mathrm{Kg} \mathrm{ha}^{-1}\right)$ & Tillering & Booting & Trimming \\
\hline 0 & $24,52^{\mathrm{NS}}$ & $14,80^{\mathrm{NS}}$ & $74,00^{\mathrm{NS}}$ \\
150 & 23,19 & 12,26 & 61,33 \\
$75+75$ & 33,51 & 10,46 & 63,33 \\
$50+50+50$ & 21,77 & 8,73 & 69,00 \\
\hline $\mathrm{CV}(\%)$ & 25,34 & 39,72 & 19,16 \\
\hline
\end{tabular}

$\mathrm{CV}(\%)$ : Coefficient of variation. NS: Not significant.

In the experiment by Tanaka et al. (2008), the increase of $\mathrm{N}$ dose caused an increase in the incidence of diseases in the two genotypes, and when $\mathrm{N}$ was not applied, the IAC-24 presented a severity of $23.4 \%$ and the IAC-60 presented $9.9 \%$. With application of $120 \mathrm{~kg} \mathrm{ha}^{-1}$, the severity of IAC-24 was $86.1 \%$ and the IAC-60 was $66.5 \%$

Embrapa Wheat (2003) reports that the excess of $\mathrm{N}$ in the wheat occurs the increase of the leaf area and the increase of the tillering, occurring the autographed foliar. Providing adequate microclimate formation for the development of disease and how the leaves become lush will potentiate the onset of diseases.

For variable number of tillers per plant the control showed a statistical difference of the other treatments, a reduction in the number of tillers was observed (Table 4). Fioreze and Rodrigues (2014) cite the plasticity of the wheat plant and some kind of interference that occurs in its cycle, can be determinant, attributing is the nutrition, light and water. These variable conditions may be attributed to the results obtained.

Table 4: Number of tillers (unity per plants) in wheat crop under dose fractioning of Nitrogen. DoisVizinhos-PR. Safra 2014.

\begin{tabular}{ll}
\hline Dose Fractioning of Nitrogen $\left(\mathrm{Kg} \mathrm{ha}^{-1}\right)$ & Tillers \\
\hline 0 & $9,19 \mathrm{~b}$ \\
150 & $12,31 \mathrm{a}$ \\
$75+75$ & $11,62 \mathrm{a}$ \\
$50+50+50$ & $11,30 \mathrm{a}$ \\
\hline $\mathrm{CV}(\%)$ & 6,41
\end{tabular}

$\mathrm{CV}(\%)$ : Coefficient of variation.

Means followed by the same letter in the column, do not differ by Tukey's test $(\mathrm{p}<0,05)$.

Mundstock (1999) reports that the number of tillers is determined by the population of plants in the area in general, changing to compensate for lack of or excess plants.Penckowski et al. (2009) that quantified the effect of $\mathrm{N}$ doses and growth reducer, it was verified that there was no change in the number of tillers, the same reported by Orso et al. (2014).

The number of tillers in the wheat crop is of great importance because the more tillers the plants have, greater their final production, since each tiller that completes the crop cycle has a viable spike. Another advantage is that these tillers are sources of energy reserve, which can be used by the plant, due to some stress.

For the hectolitre weight, it was verified that the best result occurred when two applications of $75 \mathrm{~kg} \mathrm{ha}^{-1}$ presented Hectolitre Weight (HW) of $78.09 \mathrm{hl}$ and the smallest result when the application of N presented a HW of $74.72 \mathrm{hl}$ (Table 5). These results show that the fractionation of nitrogen doses in different phenological stages, promotes higher quality and productivity, as a better use of nitrogen by the plant.

Oliveira et al. (2013) verified that there was no difference with different dosages of $\mathrm{N}$, and these dosages varied from 0 to $120 \mathrm{Kg} \mathrm{ha}^{-1}$ of $\mathrm{N}$ and the $\mathrm{HW}$ remained at $79 \mathrm{hl}$. The experiment of Trindade et al. (2006) gave a different result, and as the dose of $\mathrm{N}$ increased, linearly decreases the $\mathrm{pH}$ of the wheat.

According to Furlani et al. (2002), the occurrence of excess rainfall in crops that have reached physiological maturation may reduce HW and consequently reduce grain quality. According to Ormond et al. (2013), the pH of the wheat is what reflects in the yield of the grains in flour or semolina. The higher the HW the higher the yield, there are three types of wheat and each of these types have a specific minimum value ranging from 72 to $78 \mathrm{hl}$ (CONAB, 2016).

Tabela 5: Hectolitre weight (HW) (hl) in wheat crop under dose fractioning of Nitrogen. DoisVizinhos-PR. Safra 2014.

\begin{tabular}{ll}
\hline Dose Fractioning of Nitrogen $\left(\mathrm{Kg} \mathrm{ha}^{-1}\right)$ & Hectolitre Weight $(\mathrm{g})$ \\
\hline 0 & $74,72 \mathrm{c}$ \\
150 & $75,52 \mathrm{bc}$ \\
$75+75$ & $78,09 \mathrm{a}$ \\
$50+50+50$ & $76,88 \mathrm{ab}$ \\
\hline $\mathrm{CV}(\%)$ & 1,17 \\
\hline
\end{tabular}

$\mathrm{CV}(\%)$ : Coefficient of variation.

Means followed by the same letter in the column, do not differ by Tukey's test $(\mathrm{p}<0,05)$.

Regarding productivity, the highest yield occurred with the realization of two applications of $75 \mathrm{Kg} \mathrm{ha}^{-1}$ presenting a productivity of $194.90 \mathrm{Kg} \mathrm{ha}^{-1}$ and the lowest, was with the non-application of $\mathrm{N}$ with the 
productivity of $187.40 \mathrm{Kg} \mathrm{ha}^{-1}$ (Table 6). These results clearly demonstrate the importance of nitrogen to crop yield as well as also demonstrates that fractionation of nitrogen doses is critical for production since the plant manages to maximize $\mathrm{N}$ uptake.

Tabela 6: Productivity $\left(\mathrm{kg} \mathrm{ha}^{-1}\right)$ in wheat crop under dose fractioning of Nitrogen. DoisVizinhos-PR. Safra 2014.

\begin{tabular}{ll}
\hline Dose Fractioning of Nitrogen $\left(\mathrm{Kg} \mathrm{ha}^{-1}\right)$ & Productivity $\left(\mathrm{kg} \mathrm{ha}^{-1}\right)$ \\
\hline 0 & $187,40 \mathrm{c}$ \\
150 & $189,20 \mathrm{bc}$ \\
$75+75$ & $194,90 \mathrm{a}$ \\
$50+50+50$ & $192,20 \mathrm{ab}$ \\
\hline $\mathrm{CV}(\%)$ & 1,04 \\
\hline
\end{tabular}

CV (\%): Coefficient of variation.

Means followed by the same letter in the column, do not differ by Tukey's test $(\mathrm{p}<0,05)$.

In the experiment by Ros et al. (2003), as there was an increase in the application of N, there was an increase in production, with $30 \mathrm{~kg} \mathrm{ha}^{-1}$ of $\mathrm{N}$ producing $795 \mathrm{~kg} \mathrm{ha}^{-1}$ and $60 \mathrm{~kg} \mathrm{ha}^{-1}$ producing $1240 \mathrm{~kg} \mathrm{ha}^{-1}$. theparceling of the applications did not differentiate statistically, different from that occurred in this work.

In the experiment by Nakayama et al. (2006), there was a growing increase with the application of $\mathrm{N}$ up to the dose $158 \mathrm{~kg} \mathrm{ha}^{-1}$ where it had a production of $2810 \mathrm{~kg} \mathrm{ha}^{-1}$. TeixeiraFilho et al. (2010) verified that application of $\mathrm{N}$ in coverage, differed statistically from the application in sowing. The productivity, when applied in cover, was $3666 \mathrm{~kg} \mathrm{ha}^{-1}$, while in sowing $3544 \mathrm{~kg} \mathrm{ha}^{-1}$.

\section{Conclusion:}

The fractionation of the $150 \mathrm{~kg} \mathrm{ha}^{-1}$ dose at different times of application in the wheat crop influenced the number of tillers, hectolitre weight and productivity. However, different fractional doses should be tested in future studies to obtain more conclusive data.

\section{Future Work:}

Considering the importance of the fractionation of the application of nitrogen doses in the wheat phenological stages, it would be interesting to evaluate the application of different doses of nitrogen in the double ring stage (DR) and terminal spikelet (TE), since they are phenological stages that have a great relation in yield and final grain quality in an attempt to maximize productivity.

\section{REFERENCES}

Alvares, C.A., J.L. Stape, P.C. Sentelhas, M.L.J. Gonçalves and G. Sparovek, 2014. Koppen`sClimateClassificationMap for Brazil.MeteorologischeZeitschrift, Vol. 22, No. 6, 711-728.

Araújo, A.P. and C.T.T. Machado, 2006. Fósforo. In: Nutrição mineral de plantas. Fernandes, M.S. (ed.) 1.ed. Viçosa: Sociedade Brasileira de Ciência do Solo, 10: 253-280.

Bhering, S.B., H.G. Santos, C.V. Manzatto, I. Bognola, A.P. Carvalho, O. Potter, M.L.D. Aglio, J.S. Silva, C.E. Chaffin and W. Carvalho Junior, 2008. Mapa de Solos do Estado do Paraná. EMBRAPA/ IAPAR. Rio de Janeiro, pp: 74.

Costa, L., C. Zucareli and C.R. Riede, 2013. Parcelamento da adubação nitrogenada no desempenho produtivo de genótipos de trigo,Revista Ciência Agronômica, 44(2): 215-224.

Embrapa Trigo, 2014. Sistema de Produção. Controle das Doenças de Órgãos Aéreos. Passo Fundo.

Espindula, M.C.F., 2010. Doses e Formas De Aplicação De Nitrogênio No Desenvolvimento E Produção Da Cultura Do Trigo.Ciência e agrotecnologia, Lavras, 34(6): 1404-1411.

Ioreze, S.L and J.D. Rodrigues, 2014. Componentes Produtivos do Trigo Afetados pela Densidade de Semeadura e Aplicação de Regulador Vegetal. Ciências Agrárias, Londrina, 35(1): 39-54.

Furlani, A.M.C., O. Guerreiro Filho, R.M. Coelho, J.A. Betti and S.S. Freitas, 2002. Recomendações da comissão técnicade trigo para 2002. 3.ed. Campinas: Instituto Agronômico, 92p. (Série tecnológica APTA. Boletim técnico IAC, 167).

Goes, R.H.T.B., L.H.X. Silva and K.A. Souza, 2013. Alimentos e Alimentação Animal. Universidade Federal da Grande Dourados- Editora UFGD.

IAPAR - Instituto Agronômico do Paraná. 2008. Técnicas para a Produção de Trigo no Paraná. Prospecção para a safra.

Jesus, A and D.T.L. Ferreira, 2009. Influência das diferentes dosagens de nitrogênio aplicadas em cobertura na cultura do trigo, cultivar CD 115 na região de Cascavel-PR. Faculdade Assis Gurgacz - FAG, Cascavel, PR.

Megda, M.M., S. Buzetti, M. Andreotti, C.M.M. Teixeira Filho and X.M. Vieira, 2009. Resposta de Cultivares de Trigo ao Nitrogênio em Relação às Fontes e Épocas de Aplicação Sob Plantio Direto e Irrigação por Aspersão.Ciência e Agrotecnologia, Lavras, 33(4): 1055-1060. 
Melero, M.M., C.D. Gitti, O. Arf and F.A.R. Rodrigues, 2013. Coberturas vegetais e doses de nitrogênio em trigo sob sistema plantio direto.Pesquisa Agropecuária, Goiânia, 443: 343-353.

Mundstock, C.M., 1999. Planejamento e manejo integrado da lavoura de trigo. Porto Alegre. Ed. do Autor, p: 228.

Nakayama, F.T., R.M. Melo, L.J. Fagundes, C.J. Cavichioli and S.F. Kasai, 2006. Tilização De Nitrogênio Em Cobertura Na Cultura Do Trigo Na Região Da Alta Paulista. Pesquisa e Tecnologia, Campinas, 2(3): 20-27.

Oliveira, W.C., L.T.D. Ferreira, R.E. Lorenzeti, R.E. Rutzen, P.H.P. Lima and A.R. Malfato, 2013. Influência das diferentes dosagens de nitrogênio aplicadas em cobertura na cultura do trigo.

Ormond, A.T.S., S.A.J. Nunes, C. Caneppele, S.L.S. Silva and J.T.M. Pereira, 2013. Análise das características físicas de sementes de trigo.EnciclopédiaBioesfera, Goiânia, 9(17): 108-114.

Orso, G., L.H. Villetti, H.F. Krenchinski, P.J.A. Albrecht, P.L. Albrecht, M.D. Rodrigues and F.M. Moraes, 2014. Comportamento da cultura do trigo sob efeito de fontes e doses de nitrogênio. Cerrado Agrociências, Patos de Minas, 1(5): 44-52.

Pettinelli Neto, A., A.C. Crusciol, S.J. Bicudo, J.G. Freitas and A.L. Pulz, 2002. Eficiência e resposta de genótipos de trigo irrigado ao nitrogênio para o Estado de São Paulo. In: CONGRESSO DE INICIAÇÃO CIENTIFICA, 14., 2002, Presidente Prudente. Anais... Presidente Prudente: Unesp, CD-ROM.

Ros, C.O., L.R. Salet, L.R. Porn and C.N.J. Machado, 2003. Disponibilidade de nitrogênio e produtividade de milho e trigo com diferentes métodos de adubação nitrogenada no sistema plantio direto. Revista Ciência Rural, Santa Maria, 33(5): 799-804.

Sangoi, L., C.A. Berns, L.M. Almeida, G.C. Zanin and C. Schweitzer, 2007. Características agronômicas de cultivares de trigo em resposta à época da adubação nitrogenada de cobertura.Ciência Rural., 37: 1564-1570.

Silva, F.A.S. and C.A.V. Azevedo, 2009. Principal Components Analysis in the Software AssistatStatistical Attendance In: WORLD CONGRESS ON COMPUTERS IN AGRICULTURE 7, Reno- NV- USA: American Society of Agricultural and Biological Engineers.

Souza, W.P., B.M.E. Silva, F.A. Schlicchting and C.M. Silva, 2013. Desenvolvimento inicial de trigo sob doses de nitrogênio em latossolo Vermelho de Cerrado. Revista Brasileira de Engenharia Agrícola e Ambiental, 17(6): 575-580.

Tanaka, S.A.M., G.J. Freitas and F.P. Medina, 2008. Incidência de doenças funficas e sanidade de sementes de trigo sob diferentes doses e nitrogênio e aplicação de fungicida. SummaPhytophal, Botucatu, 34(4): 313-317.

Teixeira Filho, M.C.M., S. Buzetti, M. Andreotti, O. Arf and S.G.C. Benett, 2010. Doses, Fontes e Épocas de Aplicação de Nitrogênio em Trigo Irrigado em Plantio Direto. Pesquisa Agropecuária Brasileira, Brasília, 45(8): 797-804.

Trindade, M.G., L.F. Stone, B.A. Heinemann, D.A. Cánovas and A.A.J. Moreira, 2006. Nitrogênioe Água como Fatores de Produtividade do Trigo no Cerrado. Revista Brasileira de Engenharia Agrícola e Ambientalv, 10(1): 24-29.

Valério, I.P., F.I. F. Carvalho, C. A. Oliveira, G. Benin, Q.V. Souza, A.A. Machado, I. Bertan, C.C. Busato, G. Silveira and R.A.D. Fonseca, 2009. Seeding density in wheat genotypes as a function of tillering potential.ScientiaAgrícola, Piracicaba, 66(1): 28-39.

Yano, G.T., H.W. Takahashi and T.S. Watanabe, 2005. Avaliação de fontes de nitrogênio e épocas de aplicação em cobertura para o cultivo do trigo. Semina,

Zagonel, J., S.W. Venancio, P.R. Kunz and H. Tanamati, 2002. Doses de Nitrogênio e Densidades de Plantas com e sem Regulador de Crescimento Afetando o Trigo. Ciência rural, Santa Maria, 32(1): 25-29.

Zagonel, J. and E.C. Fernandes, 2007. Doses e épocas de aplicação de redutor de crescimento afetando cultivares de trigo em duas doses de nitrogênio. Sociedade Brasileira da Ciência das Plantas Daninhas, Viçosa, 25(2): 331-339. 